\title{
GCU
}

Glasgow Caledonian

University

University for the Common Good

\section{The role of geo-environmental factors in landscape and visual assessment for shallow- water offshore structures}

Mickovski, Bobby; Alves, Gisele

Published in:

Proceedings of the 1st Vietnam Symposium on Advances in Offshore Engineering: Energy and Geotechnics

DOI:

10.1007/978-981-13-2306-5

Publication date:

2019

Document Version

Author accepted manuscript

Link to publication in ResearchOnline

Citation for published version (Harvard):

Mickovski, B \& Alves, G 2019, The role of geo-environmental factors in landscape and visual assessment for shallow-water offshore structures. in Proceedings of the 1st Vietnam Symposium on Advances in Offshore Engineering: Energy and Geotechnics. Lecture Notes in Civil Engineering, vol. 18, Springer, pp. 81-87, Vietnam Symposum on Advances in Offshore Engineering, Hanoi, Viet Nam, 1/11/18. https://doi.org/10.1007/978-981$13-2306-5$

\section{General rights}

Copyright and moral rights for the publications made accessible in the public portal are retained by the authors and/or other copyright owners and it is a condition of accessing publications that users recognise and abide by the legal requirements associated with these rights.

Take down policy

If you believe that this document breaches copyright please view our takedown policy at https://edshare.gcu.ac.uk/id/eprint/5179 for details of how to contact us. 


\title{
The role of geo-environmental factors in landscape and visual assessment for shallow-water offshore structures
}

\author{
Slobodan B. Mickovski ${ }^{10000-0002-1792-1258]}$ and Gisele Alves ${ }^{1}$ \\ ${ }^{1}$ Glasgow Caledonian University, 70 Cowcaddens Rd, Glasgow G4 0BA, Scotland, UK
}

\begin{abstract}
Although the offshore wind power has been harvested for relatively long time, there is a lack of knowledge on the specific geotechnical and planning considerations relevant to construction of wind farms in shallow waters. The aim of this study is to propose a new integrated framework for landscape and visual assessment of shallow offshore developments in the south of Brazil and the north of Scotland. The study sites have contrasting bio-geo-climatic characteristics and, while Scotland is considered to be at the forefront of the offshore wind energy utilization, Brazil has only recently started to show interest in such developments because wind energy is considered as new but promising especially in lake areas. The focus of this study is on the geo-environmental impact assessment for shallow-water wind farms in terms of landscape capacity and vulnerability, with a special focus on the geo-environmental parameters. This study outlines the current practice in the determination of geoenvironmental parameters for planning and construction in relation to seascape/landscape assessment, while highlighting the gaps in knowledge and consideration of critical geotechnical information within a sustainability framework. A seascape capacity assessment is proposed for the two sites, where the geotechnical parameters are determined in conjunction with economic, societal, and environmental factors through a desk study, site survey and preliminary ground investigations. Additionally, construction impact assessment, risk assessment and monitoring of the geo-environmental variables are proposed as tools for enhancing the engagement with the planning authorities and affected communities. The future refinements and enhancements of this framework will depend on the efforts of the geotechnical engineering community to persuade the planning decision makers, affected communities, and the clients of the importance of the life cycle geo-environmental parametrization for the sustainability of the project.
\end{abstract}

Keywords: Wind Energy, Shallow Waters, Sustainability, Geotechnical Engineering, Landscape Capacity, Vulnerability.

\section{Introduction}

Wind energy has been recognized as one of the most mature technologies in use, especially in shallow waters [1], and thus, very important in renewable energy production. However, it has also been recognized that offshore wind projects can present environmental problems such as noise and vibration, landscape alteration, in addition 
to the negative effects on flora and fauna as well as on the communities adjacent to the wind power production facilities [2]. Hence, to ensure the viability of projects with perceived potential for environ-mental threat, it is necessary to include public consultations for the feasibility of projects [3].

At present, the offshore wind energy options are not only related to the generation capacity of the wind turbines but also to site adequacy for construction and operation [4]. This contributes to the tendency of wind farms to be expensive when compared to other forms of power generation [5] with the expenses raising with the wind farm distance from the coast and depth to which the structures will be installed [6]; wind speeds tend to be higher away from the coast [7] and there, more robust structures requiring more materials, services and logistics need to be designed [8].

In order to minimize both the environmental impacts and the high costs of the offshore wind farm construction, but also to consider the effects of such project on the adjacent communities as per the European Environmental Impact Assessment (EIA) Directive (85/337/EEC), a process for landscape and visual impact assessment (LVIA) is carried out in the UK. This process, commonly used for onshore windfarms, considers landscape and visual sensitivity against a number of key criteria (landscape context, scale and openness, landform, landscape pattern, built environment, perceptual qualities, visual amenity, tourism, recreation, cultural heritage, and transportation; [9]) including any cumulative effects associated with existing and consented wind energy developments. However these criteria do not include geotechnical parameters which are critical for siting a windfarm from a constructability point of view. Furthermore, this process, while relatively successfully piloted for planning onshore developments, has yet to be expanded to include seascapes (i.e. the particularities associated with the coastal zone or littoral at the conjunction of land and sea, combining maritime, coast and hinterland character.

The aim of this study is to highlight the importance of geo-environmental parameters in a novel, integrated impact assessment framework for windfarm developments in shallow waters. To achieve this aim, we will review the current LVIA framework, propose potential enhancements which will include the geotechnical parameters across the project stages and briefly illustrate a high-level application of this framework at two potential developments in contrasting geo-environmental regions.

\section{Methods}

\subsection{Existing (S)LVIA framework}

The scope of the (seascape) landscape and visual assessment encompasses the geographical reach of the area of land likely to be affected by onshore windfarm development. It starts with establishing the baseline in terms of identifying and surveying areas of specific coastal character, before the impact of the windfarm development is assessed based on the technology requirements. Based on this assessment, different options for the layout and design of the development are considered before the development is sited, the sensitivity of the environment quantified and recommendations are made in the Environmental statement [10]. Based on the fact that this process is 
done during the planning stage of the project, only a limited number of environmental parameters are considered. Soil-related parameters are often excluded from this analysis although the soil environment forms the basis of sustainable geotechnical engineering (Fig.1a), especially when the foundation design and construction (Fig 1b) of windfarm developments re considered.
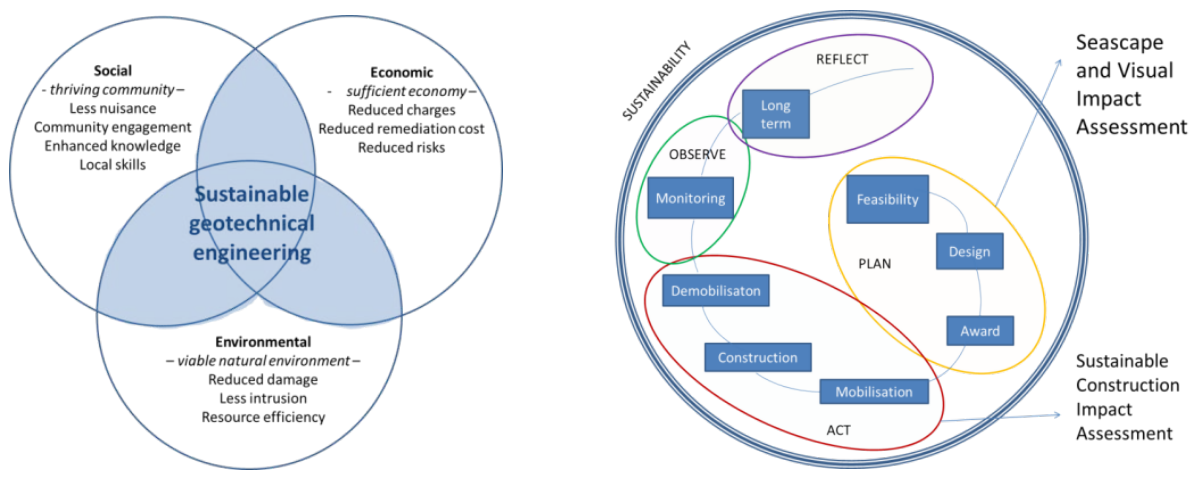

Fig. 1. a) Sustainability aspects of geotechnical engineering related to windfarm development. b) The new proposed SLVIA framework that incorporates geotechnical engineering parameters throughout the lifecycle of the project in order to enhance sustainability.

\subsection{Case study sites}

To illustrate the application of the proposed framework above, two sits with contrasting geo-environmental characteristics have been chose, the Lagoa dos Patos in Brazil and Catterline Bay in Scotland (Fig 2.)
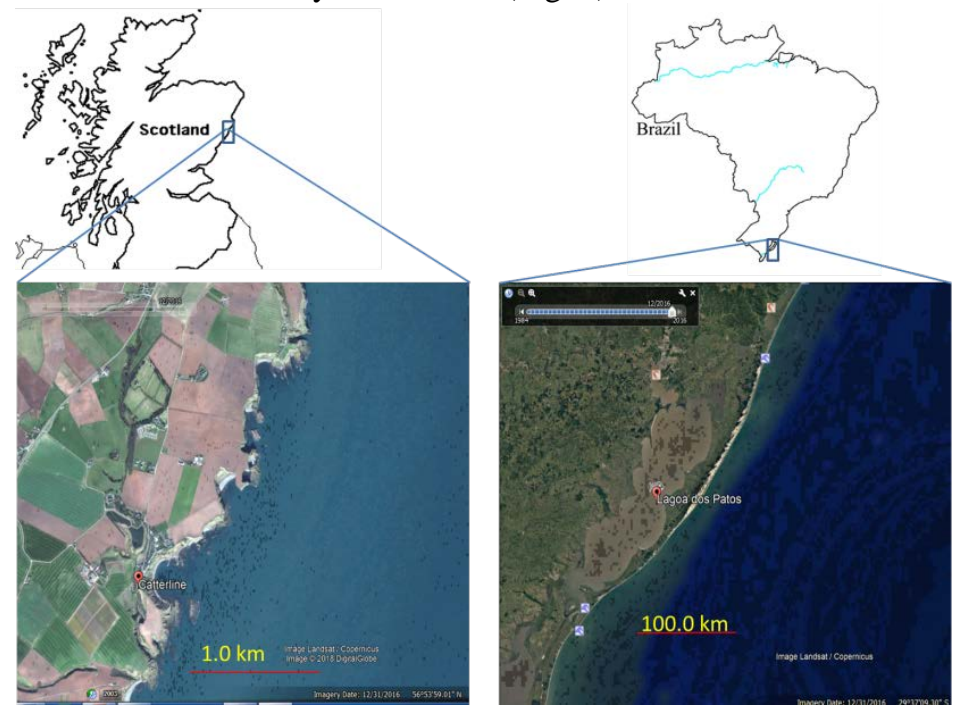

Fig. 2. Location of the two study sites. 
Lagoa dos Patos (LDP) lies in a flat to gently undulating coastal plain within a Holocene and Pleistocene barrier system comprising dune field peninsulas while Alluvial fan sediments derived from igneous and metamorphic rocks of the Precambrian shield and sedimentary and volcanic rocks of the Paraná basin rest further inland. This lagoon is evidently the remains of an ancient depression in the coastline shut in by sand beaches built up by the combined action of wind and currents. The shallow lagoon is located at sea level, but its waters are affected by the tides and are brackish only a short distance above the Rio Grande outlet into the Atlantic Ocean. The JacuíGuaíba and Camaquã Rivers empty into it, while the navigable São Gonçalo Channel, which enters Lagoa dos Patos near the town of Pelotas, connects Lagoa dos Patos to Lagoa Mirim to the south [11]. The lagoon region includes a large number of aquatic (e.g. brackish-salt and freshwater coastal lagoons, swamps, marshes, seasonal and permanent freshwater ponds, rivers, and streams) and terrestrial (e.g. Uruguayan savanna, Alto Paraná Atlantic forests, Araucaria moist forests, and Atlantic coast restingas) habitats.

Catterline Bay (CB) is surrounded by a $300 \mathrm{~m}$ long, $30 \mathrm{~m}$ high coastal slope located along the north-east Scottish coast, $30 \mathrm{~km}$ south of Aberdeen. Catterline comprises a series of exposed, mainly vegetated, slope sections interspersed with gullyoutcrop forms ranging in height between 2 and $10 \mathrm{~m}$. The slope is vegetated with a range of vegetation types (grasses, herbs, shrubs and planted trees) covering approximately $20 \%$ in winter to approximately $80 \%$ of the slope during the vegetative period. Private residential properties are located along the crest of the slope while a seepage line is visible adjacent to the former pumping house located mid-slope, as well as 25 $\mathrm{m}$ north of the pumping house, indicating a series of springs with seeping water flowing along naturally formed gullies towards the gravel drain along the access road which, in turn, discharges into the sea at the landing stage which is used by the local diving club. Remnants of a sea wall defence comprising sections of rounded boulders, mass-poured concrete, anchored gabions, and concrete cubes exist at the toe of the slope and delineates the slope from the beach. The line of the sea wall is damaged to various degrees due to the action of the waves and seepage from the slope which resulted in a variety of failures on the slope [12].

\section{$3 \quad$ Results and analysis}

\subsection{Proposed new SLVIA framework, integrating geo-environmental issues}

A new, integrated framework for landscape and visual assessment of shallow offshore developments [Fig 1b] will have to include the characteristics of the seascape (visual and physical conjunction of land and sea, combining maritime, coast and hinterland character). A seascape capacity assessment that includes the geological and geotechnical characterization should aim to preserve the significant geo-environmental engineering characteristics of the existing coastal character (e.g. zones with similar drift/solid geology, similar soil strength characteristics, similar wave loading), which should be considered against the geo-environmental engineering attributes of the shallow water windfarm development (e.g. foundation types, construction sequence, ac- 
cess requirements). In the case of LDP this capacity assessment would distinguish between shallow ocean waters, the barrier system, lagoon, and alluvial plains as the minimum. At CB, as a much smaller area, this assessment would consider the shallow waters, cliff system, and glacial till formation inland. At this stage, the attributes of the development would be set out in the project task - as a minimum providing energy supply for the communities adjacent to the development - one very small rural community at CB and a number of urban, rural, and indigenous communities at LDP.

After the attributes of the development have been recognized, the assessment will consider which characteristics of the seascape are most likely to be affected by the development, which will then inform the survey, analysis, and assessment of landscape character (i.e. the basis of a sensitivity assessment) during different stages of the project development (not only planning but also construction, operation and maintenance, monitoring and decommissioning) (Fig 1b). In this respect, the new SLVIA framework should take into accout the geotechnical parameters in conjunction with economic, societal, and environmental factors through a desk study, site survey and preliminary ground investigations. For example, existing geological maps, ground investigation (intrusive and geophysical) and bathymetric surveys can be used in conjunction with an established geodetic (incl. tidal) datum and projection for all the work associated with the development. At this stage, targeted sampling of soils (in case of LDP) or rock (at CB), in situ cone penetration tests (CPT) at LDP, in situ measurement of soil moduli and other dynamic properties (e.g. seismic cone, P-S logging) at LDP should take place together with measurements of expected wind and wave loading and the results recorded for future use. The SLVIA would, at this stage, be informed of the field layout, foundation specimen design, inter-array and export power cabling, offshore substations, systems installation and operations and maintenance (O\&M), all in relation to the geo-environmental factors such as sea and land access to the site (e.g. navigability and tracks), protection of biodiversity across the seascape, nuisance and disruption for local communities, etc.

During the design stage, a construction impact assessment should be carried out which will provide guidance on the assessment of impacts during construction and their significance during and after construction (e.g. benthic disruption during cable or foundation laying, vegetation selection for stability of landside access tracks). During construction, the site evaluation guidelines should be reviewed together with the risk mitigation measures and monitoring techniques outlined at planning stage. Quantitative long-term coastal and nearshore marine monitoring data (e.g. swath bathymetry, terrestrial laser scanning, digital aerial photography) will enable understanding of coastal processes and changes which will, in turn, inform the engineering decision-making [13]. Simulated 3D construction and testing operation/maintenance scenarios using geographic information systems (GIS) together with digital elevation models will enhance the engagiement with the planning authorities and affected communities. 


\section{Conclusions}

It is clear that the proposed framework has to be tried and tested and that, in its present, conceptual, form needs refinement. The future refinements and enhancements will depend on the efforts of the geotechnical engineering community to persuade the planning decision makers, affected communities, and the clients of the importance of the life cycle geo-environmental parametrization for the sustainability.

The information collected, with geotechnical focus, will need to be collected, stored, and used as required $[7,13]$ not only during the project but also as a basis for relevant future projects. For this purpose, a Building Information Modelling (BIM) approach would enable involvement of all parties in the decision making at any project stage, as well as availability and sharing of information in the most efficient way.

\section{References}

1. Koh, J.H. Ng, E.Y.K.: Downwind off-shore wind turbines: Opportunities, trends and technical challenges. Renewable and Sustainable Energy Reviews. 54 pp. 797-808 (2016).

2. Aitken, M.: Wind power and community benefits: Challenges and opportunities. Energy Policy. 38(10), 6066-6075 (2010).

3. BWEA - British Wind Energy Association, Best pratice guideline: Consultation for offshore wind energy developments. http://www.energy.ca.gov/windguidelines/documents, last accessed 21 October, 2017.

4. Le, T.M.H., Eiksund, G.R., Stroem, P.J. Saue, M.: Geological and geotechnical characterisation for offshore wind turbine foundations: A case study of the Sheringham Shoal wind farm. Engineering Geology. 177, 40-53 (2014).

5. Levitt, A.C., et al.: Pricing offshore wind power. Energy Policy. 39(10), 6408-6421 (2011).

6. Higgins, P., Foley, A.: The evolution of offshore wind power in the United Kingdom. Renewable and Sustainable Energy Reviews. 37(0), 599-612 (2014).

7. Cavazzi, S., Dutton, A.G.: An Off-shore Wind Energy Geographic Information System (OWE-GIS) for assessment of the UK's offshore wind energy potential. Renewable Energy. 87(1), 212-228 (2016).

8. Sovacool, B.K., Enevoldsen, P.: One style to build them all: Corporate culture and innovation in the offshore wind industry. Energy Policy 86, 402-415 (2015).

9. Grant, A., Anderson, C.: Moray Wind Energy Landscape Capacity Study. Appendix Report - Detailed sensitivity assessments. The Moray Council, Elgin (2012)

10. Scottish Natural Heritage. Offshore Renewables - guidance on assessing the impact on coastal landscape and seascape. SNH, Edinburgh, Scotland (2012).

11. Hales, J., Petry, P.: Laguna dos Patos - Freshwater Ecoregions of the World, http://www.feow.org/ecoregions/details/laguna_dos_patos, last accessed 06 February, 2018.

12. Mickovski S.B., Santos O., Ingunza P.M.D., Bressani L.: Coastal slope instability in contrasting geo-environmental conditions. Geotechnical Engineering for Infrastructure and Development, 1801-1806 (2015).

13. Colenutt A., Westhead K., Evans J., McVey S., Le Bas T.: Interpreting monitoring data for shoreline and geohazard mapping. Maritime Engineering 168, 118-124 (2015). 